Review

\title{
Wastewater conservation and reuse in quality vegetable cultivation: Overview, challenges and future prospects
}

\section{Adejumoke Abosede Inyinbor ${ }^{\mathrm{a}, *}$, Olugbenga Solomon Bello ${ }^{\mathrm{b}}$, Abimbola Peter Oluyori ${ }^{\mathrm{a}}$, Henry Eromosele Inyinbor ${ }^{c}$, Ayomide Emmanuel Fadiji ${ }^{\mathrm{d}}$}

a Department of Physical Sciences, Industrial Chemistry Programme, Landmark University, P.M.B.1001, Omu-Aran, Kwara State, Nigeria

${ }^{\mathrm{b}}$ Department of Pure and Applied Chemistry, Ladoke Akintola University of Technology, P.M.B 4000. Ogbomoso, Oyo State, Nigeria

${ }^{\mathrm{c}}$ Department of Medical Microbiology, Federal Medical Centre, P.M.B. 14, Bida, Niger State, Nigeria

${ }^{\mathrm{d}}$ Department of Pure and Applied Biology, Ladoke Akintola University of Technology, P.M.B 4000, Ogbomoso, Oyo State, Nigeria

\section{A R T I C L E I N F O}

\section{Keywords:}

Food security

Vegetable

Agro-industrial wastewater

Domestic wastewater

Irrigation

Microbial contamination

\begin{abstract}
A B S T R A C T
The serious water scarcity experienced across the globe and the desire for sufficient food production all year round to combat hunger, poverty and malnutrition necessitate the need for wastewater reuse in irrigation. Wastewater has varied compositions that affect the growth of different crops positively, they may also be a source of dangerous pollutant. Heavy consumption of vegetables have been encouraged for its nutritional and health advantages. Hence, their production and cultivation have increased globally. While the nutritional advantage of vegetables is appealing, their high susceptibility to harbor and spread pathogenic microbes call for serious concern. Activities such as transportation, improper handling and packaging amongst others are sources of vegetable contamination. Irrigation water and techniques however present greater danger. Agro-industrial wastewater of a ready-to-eat vegetable (RTEv) industry operating a closed system may reintroduce microbes to vegetable gardens. The use of raw domestic wastewater, either black or grey water in vegetable cultivation presents attendant challenges which must be handled with utmost precaution. This review is focused on the dangers associated with the reuse of agro-industrial and domestic wastewater, precautions required as well as possible preventive/reduction measures. The possible dangers associated with "crude irrigation techniques" used in vegetable cultivation in the Southwestern part of Nigeria are presented. This work will no doubt serve as a tool for policy makers and environmentalists in enlightenment and awareness campaigns in educating most rural dwellers who are ignorant of these dangers.
\end{abstract}

\section{Introduction}

Food security is one of the focuses of the post 2015 developmental agenda and various sectors worldwide are greatly concerned about the African continent on this subject matter (Termeer, Drimie, Ingram, Pereira, \& Whittingham, 2018). The target is towards meeting the dietary need and food preference for healthy and active life. Important focuses remain physical, social and economic access to food, food safety, food sufficiency as well as the nutritive properties of food (FAO, 2009). Hence inexhaustible line of challenges affect food security, a few of which are climate and weather pattern, environmental degradation and pollution. One indicator of food insecurity is the severe hike in international food price which has limited accessibility to food globally, thus leaving over one billion people undernourished (Cornia, Deotti, \& Sassi, 2016). Good nutrition is of importance to people of all ages and under nutrition is said to be responsible for $45 \%$ of under-five death. This has a great association with malnutrition hence good nutrition can significantly contribute to reduction in under five mortality (Kramer \& Allen, 2015).

The drive for food availability is on the increase by nations and agro activities are geared towards achieving this move. All year round crop production is only possible via good and effective irrigation which requires considerable high volume of water (Vanham et al., 2018). Challenges associated with farming via irrigation are enormous. Paramount among them is the high water scarcity currently being experienced globally (Liu, Liu, \& Yang, 2016). Water conservation via wastewater reuse has been identified as a means of industrial and water sustainability (Matsumura \& Mierzwa, 2008; Vergine et al., 2017). Wastewater reuse is obviously of immense benefit in agricultural activities. It serves as a means of nutrient preservation, preserves our

\footnotetext{
* Corresponding author.

E-mail address: inyinbor.adejumoke@landmarkuniversity.edu.ng (A.A. Inyinbor).
} 
water bodies from pollution, ensures an economical crop production as it increases crop yield thus reducing fertilizer consumption (Gatta et al., 2015; Libutti et al., 2018). Wastewater reuse has been globally embraced for crop irrigation and other agro activities (Chan et al., 2017; Muñoz et al., 2009). Its use however must be with great caution in order to ensure clean crop production.

The use of treated wastewater in agro activities comes with attendant challenges. First, wastewater contains varying degree of pollutants depending on their source. The various wastewater sources which include agro-industrial, household or grey water, municipal wastewater and hospital wastewater are all unique in their composition. These categories of wastewater have been used for irrigation purposes over the years either in their raw state or after treatment. These have their attendant effects on the irrigated crop and by extension on human. The sanctity of food crops produced via irrigation depends largely on irrigation water content amongst others. While organic and inorganic pollutants may bio-accumulate in crops and vegetables, the presence of pathogens, enteric bacteria and viruses are considered most threatening for vegetables (Heaton \& Jones, 2008).

Vegetables are a group of crop easily grown by irrigation. They can be eaten raw or with limited processing, hence their consumption easily causes serious health challenges if contaminated. Vegetables are consumed by all categories of economy. Their propagation requires only small land and minimal efforts, hence its viral cultivation amidst the low income earner (Mritunjay \& Kumar, 2015). Hunger, poverty and malnutrition are serious challenges in Sub-Saharan Africa (SSA) and these three are more associated with rural dwellers (Prosekov \& Ivanova, 2018; Xie, You, Wielgosz, \& Ringler, 2014). Over 70\% of the poor in SSA lives in the rural area and solely depends on agricultural activities for their survival (Arouna, Lokossou, Wopereis, Bruce-Oliver, \& Roy-Macauley, 2017). These rural dwellers greatly use and depend on vegetables to complement staple starchy food as well as increase their food variety (Uusiku, Oelofse, Duodu, Bester, \& Faber, 2010). Vegetables are cultivated on available spaces around the residential as well as various farm sites. Agricultural activities in SSA currently depends majorly on rain. However, crude irrigation using raw domestic wastewater is mainly practiced for vegetable cultivation within and around residential areas. This practice may be accompanied by high risk since domestic wastewater may contain very deadly pollutants. No doubt, vegetable consumption holds great benefits. However, ensuring its sanctity is of utmost importance in order to ensure consumer safety.

The global consumption of vegetables has greatly increased (Caradonna et al., 2017; Ssemanda et al., 2017). Similarly, the campaign for adequate consumption of fruits and vegetables has been on for decades in the developed nations. Five daily servings of fruits and vegetables is recommended in most developed nations (Brookie, Mainvil, Carr, Vissers, \& Conner, 2017). This is done to better promote healthy living, reduce the risk of cardiovascular related diseases, overweight health situations and challenges as in the case of obesity and type II diabetes as well as cancer (Rekhy \& McConchie, 2014; Wang et al., 2014). Great acceptance of this recommendation jacked up the market of ready-to-eat vegetables (RTEv) as consumers consider it a healthy and convenient food (Castro-Ibáñez, Gil, \& Allende, 2017). However, vegetables which have been considered a tool for healthier living have also been frequently linked to the outbreak of food borne diseases which cause about 5072 deaths in the United State (US) annually (Alegbeleye, Singleton, \& Sant'Ana, 2018). Sources of contamination have been identified to vary from environmental to human handling and exposure to animals. Inappropriate fertilizer and manure application, intrusion of livestock on the field and the use of unsafe water for irrigation, all contribute to on-site vegetable contamination (Mir et al., 2018). For instance, domestic wastewater (grey and black water) contains high faecal coliform while wash water in RTEv industries may be rich in various microbes. These may be a source of serious contamination if used for vegetable irrigation. While some reviews had their focus on reclaimed water treatment technologies (Norton-
Brandão, Scherrenberg, \& Lier, 2013), sustainability of irrigation water/practice (Mechelen, Dutoit, \& Hermy, 2015; Mutambara, Darkoh, \& Atlhopheng, 2016; Tal., 2016), sustainability of irrigation system (Wazed, Hughes, O'Connor, \& Calautit, 2018), development in irrigation technologies (Nakawuka, Langan, Schmitter, \& Barron, 2018) and various contaminations and risks associated with reclaimed water reuse in irrigation (Alegbeleye et al., 2018; Allende, Truchado, Lindqvist, \& Jacxsens, 2018; Chen et al., 2018; Elgallal, Fletcher, \& Evans, 2016; Caicedo et al., 2019), reviews focusing on dangers associated with wastewater reuse within RTEv industries operating a closed system does not exist. In addition, irrigation technology is in its emerging state in several developing nations. Its practice, particularly amongst rural dwellers involves a crude approach which mainly employs domestic wastewater as water source for vegetable propagation. Domestic wastewater are known to be laden with emerging contaminants (ECs) such as pharmaceuticals and personal care product wastes. While ECs are a subject of discuss as well as a concern in developed nations, little or no attention is given to these contaminants in developing nations. This review also discusses the danger of crude irrigation practice viz-a-viz popularly consumed food such as vegetables. Hence the importance of this work.

Two categories of wastewater, agro-industrial and domestic wastewater, in vegetable propagation are herein discussed. The agro-industrial wastewater reuse in crop irrigation identifies possible challenges that may be associated with closed system in vegetable propagation and processing industries while the domestic wastewater reuse in vegetable irrigation highlights issues that may arise from crude irrigation, particularly in the developing nations. Each of these irrigation water sources, their methods of treatment as well as shortcomings of such treatments are discussed in a brisk with emphasis on critical pollutants which may subsist despite applied treatment techniques. Facts obtained from studies investigating the impacts of irrigation water on vegetables may serve as tools and yardsticks in the formulation of policies which will globally safeguard the health of vegetable consumers.

\section{Method}

Science direct which contributes the highest percentage to Scopus data base was basically used to harvest relevant literature for this study. Few articles were similarly sought out via google search engine. Several key words were used in the search for literature, these include; Food security, food safety, wastewater conservation and reuse, wastewater for irrigation, domestic wastewater in crop cultivation and vegetable propagation, agro-industrial wastewater in crop cultivation and vegetable propagation, ready to eat vegetables. Collected manuscripts were screened based on their relevance to the objective of this work considering also the year of publication. Relevant manuscript published from 2007 to 2018 were used for this work. Selected studies from each continent were used as representative articles to establish a broad view and a global scenario of increased production and consumption of vegetables, microorganism presence in vegetables and outbreak of diseases traceable to vegetable consumption. A few published manuscripts discussing such scenario in Nigeria were also articulated herein. A total of one hundred and thirty four manuscripts which were drawn majorly from Journals focusing on food, agriculture and the environment were finally used for this work.

\section{Agro-industrial wastewater as water for irrigation}

Agro-industries are industries greatly explored by developing nations in order to eradicate their basic need of hunger and combat poverty (Teh, Wu, \& Juan, 2014). These industries consume and generate a huge volume of wastewater largely rich in organic materials while their other components depend on type of industry. Agro-industrial wastewater can be a source of great environmental pollution 


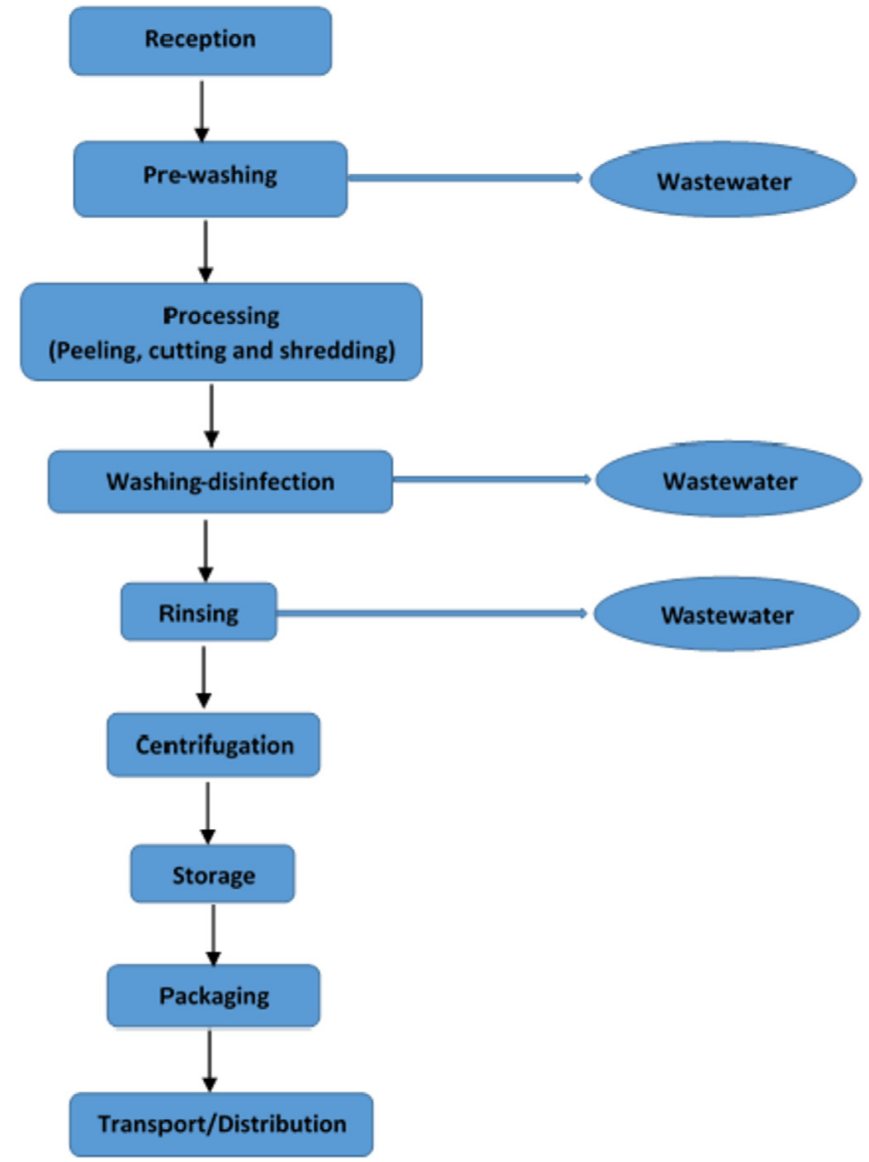

Fig. 1. Flow chart showing processing steps in ready-to-eat vegetable industries and possible wastewater generation points.

and by extension a serious threat to human. Various agro-industrial wastewater emanate from slaughter houses, fish farms, pig farms, dairy, livestock and vegetables farms/processing (Wang et al., 2016).

Vegetable processing may involve minor processing activities such as washing, chopping and/or slicing or advanced processes in which processes will involve heat (in blanching) and canning. In any case, the washing, cleaning and cooling of processed vegetables consume large volumes of water (Lehto, Sipilä, Alakukku, \& Kymäläinen, 2014). Reuse of water in this sector is therefore of paramount importance in ensuring continuous economic water availability, process water sustainability as well as environmental protection (Salomonsson, Jacxsens, Perseyn, \& De Meulenaer, 2014).

\subsection{Component of wastewater from ready-to-eat vegetable processing} industries

Ready-to-eat vegetables (RTEv) are vegetables which have only gone through minor processes such as removal of dirts, washing, cutting, peeling, slicing, shredding, drying and packaging. The modified Maffei, Alvarenga, Sant'Ana, \& Franco, 2016 RTEv processing steps is presented in Fig. 1. The demand for this category of food is based on the convenience it offers as well as demands for good nutrition (de Oliveira, de Souza, Bergamini, \& De Martinis, 2011; Maffei et al., 2016). Production and consumption of RTEv has greatly increased across the US (de Oliveira et al., 2011), Asia (Zhou, Helen, \& Liang, 2011), Europe (Nousiainen, Joutsen, Lunden, Hänninen, \& Fredriksson-Ahomaa, 2016), Middle East (Faour-Klingbeil, Murtada, Kuri, \& Todd, 2016) and Africa (Ssemanda et al., 2017).

Wastewater from the prewashing stage, disinfecting water and rinsing stage constitutes the final huge volume of wastewater generated from the RTEv processing industries (Fig. 1). Wastewater from each of the processing stages have their distinct characteristics. They are usually characterized by high loads of organic agents, salts, cleansing agents, blanching agents, suspended solid such as soil particles and fibers as well as pathogens. Specifically, wastewater from the disinfecting section will be rich in chlorine since chlorine is the common disinfectant used in vegetable processing industries (Ömez \& Kretzschmar, 2009). Non-biodegradable pollutants such as surfactants and pesticides may also form a component of RTEv wastewater. The abundant usage of pesticides results in their accumulation in the peels and skins of vegetables and their eventual release into wash water during washing (Jiménez-Tototzintle, Oller, Hernández-Ramírez, Malato, \& Maldonado, 2015; Damalas \& Khan, 2017).

Microbial contamination in vegetables is of great concern. Vegetables possess a high tendency to harbor and propagate microbes via cross contamination in their handling and processing stages (Prakash, Baskaran, Paramasivam, \& Vadivel, 2018). For instance, vegetables are known to be moisture and nutrient rich. Their tissues becomes disrupted during cutting, dicing and slicing thus exposing nutrient and moisture for better microbial proliferation (Bahram-Parvar \& Lim, 2018). Vegetables may have also been contaminated by microorganisms while growing in field via exposure to air and wild animals. Harvesting equipment, packaging and transportation containers may also result in pathogenic contaminations (Maffei et al., 2016). Washing, disinfection and rinsing stages are targeted towards ensuring that pathogens amongst other pollutants do not cross to consumers. A huge volume of water is used in these stages. Therefore, the sustainability of RTEv industries demands available and cheap water source. Hence the call for water reuse and circulation within the system. The later however calls for serious caution as such wastewater may serve as a source and vehicle for microbes' dispersal. A closed system (Fig. 2), in which wastewater generated from the various washing stages is used for vegetable garden irrigation have high tendency to carry microbes back to the garden. Until now, knowledge in the area of possible pathogen carry over to the garden in a closed vegetable processing industry is scarce. Since RTEv are not further processed prior to consumption, their clean production should not be compromised. Expositions on possible contamination route as well as calls for cleaner productions viz-a-viz establishment of policies that guide into clean and healthier production can never be overemphasized.

3.1.1. Content and reuse of wastewater from vegetable processing industries: a review of recent literature

Effective management of water resources will birth waste sustainability in RTEv industries. The quality of wastewater for reuse here is however of great importance in order to ensure safety of end consumers.

3.1.1.1. Vegetable processing wastewater: nature, content and treatment

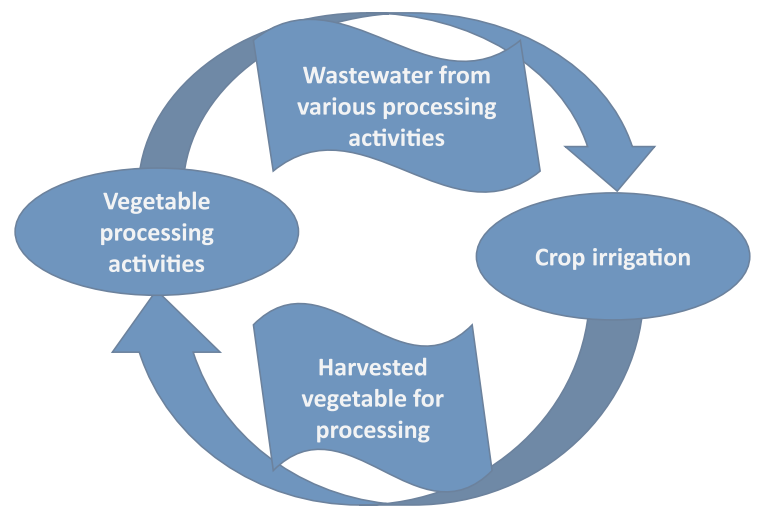

Fig. 2. Closed system in vegetable processing industry. 
techniques. The content of vegetable wash water for carrot, onion, escarole and spinach processing have been reported. Interest of this research was based on possible alternative disinfection technique as against the usual chlorination method. Ozonation, Ultraviolet-C and ozonation/ultraviolet-C combination techniques were investigated as possible alternatives. Comparing the wash water with fresh water used in the washing process, the chemical oxygen demand (COD) increased about twice in escarole and spinach wash water, onion wash water experienced about thirty eight times increase in COD while carrot wash water experienced $7.0 \mathrm{mg} / \mathrm{L}$ increase in COD. Highest turbidity was reported for onions wash water followed by spinach, carrot and escarole wash water respectively. Microbial content of wash water multiplied by minimum twice when compared with the initial clean water. Onion wash water was characterized by a high microbial count compared with others. Ozone flow rate of $80 \mathrm{mg} / \mathrm{min}$ was found effective against microbes (yeast, bacteria and molds) while eight minutes irradiation sufficiently reduced microbial content of spinach wash water and $30 \mathrm{~min}$ irradiation had no significant effect on onion wash water. Physicochemical parameters of the vegetables wash water were affected by ozonation, Uv radiation and ozone/Uv radiation (Selma, Allende, Lo'pez-Ga'lvez, Conesa, \& Gil, 2008). In another study, the content of synthetic lettuce process wash water has been reported. The study which focused on establishing the best conditions for process water disinfection via electrolytic method used five $E$. Coli strains. High COD, chloride content and conductivity amongst others characterized the wash water. Microbe inactivation was reported to be effective at high current density. This study revealed that combination of high current density, flow rate and doping level will synergistically give a higher rate of microbial inactivation (Gómez-López, Gobet, Selma, Gil, \& Allende, 2013). The content of artichoke wastewater and efforts towards their organic content and solids removal has been reported. Focus in this study centered on environmental impact reduction, useful compound recovery as well as cost reduction via water and energy saving means. Artichoke wastewater is said to be rich in phenolic compounds and flavonoids. Ultrafiltration was used to remove suspended solids while two different selective nano-filtration membranes successfully isolated phenolic compounds and sugars separately (Conidi, Cassano, \& Garcia-Castello, 2014). Wastewater obtained from garlic washing and slicing was investigated for its suitability in lotus cultivation irrigation. The wastewater was found to be very rich in COD, suspended solids and $\mathrm{NH}_{3}-\mathrm{N}$ to an extent that it affected lotus root and ultimately, its growth. Simple biological purification improved the suitability of the wastewater for application in lotus growth (Pang, Feng, \& Wang, 2014). In order to ascertain the possibility of water recycling in fresh cut lettuce producing industry, Anese, Maifreni, Bot, Bartolomeoli, \& Nicoli, 2015 studied possible microbe contaminant removal from a simulated lettuce wastewater via ultrasound system technique. The use of continuous ultrasound in synergy with the accompanying temperature gave a complete inactivation of $E$. coli and $S$. enterica and $58 \%$ L. monocytogene. However, L. monocytogene showed resistance to temperature controlled ultrasound system treatment technique (Anese et al., 2015). High power ultrasound (HPU), peroxyacetic acid (PAA) and a combination of HPU/PAA was used as an alternative to the usual chlorination technique in water sanitation of fresh cut vegetable industry. Synthetic lettuce wastewater was generated in the laboratory and content characterization showed high COD, turbidity and $\mathrm{pH}$. Murine novo virus (MNV) inactivation was the focus here. MNV was found resistant to HPU treatment even after $1 \mathrm{~h}$ of treatment while $5 \mathrm{~min}$ exposure of $80 \mathrm{mg} / \mathrm{L}$ PAA gave complete MNV inactivation. HPU/PAA treatment did not yield a better result compared with the PAA-alone treatment. It was concluded that the use of PAA alone can prevent viral cross contamination (Sanchez, Elizaquível, Aznar, \& Selma, 2015). Recently, the use of solar treatments as alternative to the usual chlorine inactivation was reported by Nahim-Granados, Sánchez Pérez, \& Polo-Lopez, 2018 Targeted microbes in this study are E. coli and S. enteritidis. The wastewater used was synthesized following the characteristic of wastewater obtained from a local fresh cut industry in Spain. A combination of biotreatment with $\mathrm{TiO}_{2} / \mathrm{H}_{2} \mathrm{O}_{2}$ photocatalysis were the methods employed. While $\mathrm{H}_{2} \mathrm{O}_{2}$ /solar process greatly inactivated both microbes, $S$. enteritidis showed higher resistance compared with $E$. coli for solar inactivation. Hence, $\mathrm{H}_{2} \mathrm{O}_{2} /$ solar technique was recommended as the best inactivation technique (Nahim-Granados et al., 2018).

Wastewaters from vegetable processing industries have been investigated for possible carry-over of protein from the vegetable to the wash water. Samples of wastewater collected from three vegetable processing industries in Belgium were investigated for $\mathrm{pH}$, crude and non-protein content as well as the influence of protein carry-over. Protein content of the wash water was found to be significantly high. Protein content of the wash water was said to be influenced by methods of processing as well as degree of vegetable cutting (Salomonsson et al., 2014). Ghimpusan, Nechifor, Nechifor, Dima, \& Passeri, 2017 recently identified the complexity of vegetable processing wastewater. They presented a study which utilized advanced treatment techniques including biological tanks, ozonation and ultrafiltration. Techniques introduced addressed the COD content of the wastewater greatly, other investigated parameters were brought below the required minimum limit.

Based on the fore-going review, wastewater from RTEv is usually characterized by high organic content vividly depicted by their large COD values. The quality of RTEv wastewater largely depends on the exact vegetable type, nature and quality of soil on which the vegetable was grown as well as irrigation water type and system. Generally, salts, dissolved and suspended solids, nitrogen, ammonia, nitrate, nitrite, surfactants, cleaning agents, potassium, pesticides and pesticide residues, oil and grease as well as various classes of microbes viz viruses, bacteria and fungi form the content of RTEv wastewater. Of important note are techniques such as PAA and $\mathrm{H}_{2} \mathrm{O}_{2}$ /solar which were effective in the inactivation of problematic microbes.

\subsubsection{Sustainable water drive in RTEv industries: wastewater reuse in} vegetable propagation. A work which focuses on possible microbiological risk and pathogenic health risk of crop irrigated with treated agro-industrial wastewater amongst others has been recently reported. This study was carried out in a closed-circle system of vegetable cultivation to processing. Discharged wastewater by various ready-to-eat vegetable industries within the location is transferred to a wastewater treatment plant (WWTP) where it undergoes the first two stages of wastewater treatment. Tertiary treatment was only carried out on demand. Their results revealed bacteria re-growth in the tertiary treated wastewater tank in a season hence high concentration of $E$. coli, fecal coliform and fecal enterococci were reported in the tertiary treated wastewater. They concluded that there was no microbial contamination of vegetable crops. This is however traced to the fact that these industries practice drip irrigation hence no contact of irrigation water with the crop. They suggested that long term effect on the soil will be an important study (Libuiti et al., 2018). The study within a closed agroindustrial sector has also been reported. Wastewater from ready-to-eat vegetable processing industries goes through the three stages of wastewater treatment was used. Their study focused on fecal indicator as related to plant and the edible part of the crop amongst others. They discovered that wastewater from vegetable processing was highly polluted while the various component of the agro-industrial wastewater had great resemblance with municipal wastewater. E. coli was found to be present in the wastewater after secondary treatment and was consequently eliminated by the eventual UV disinfection in the tertiary treatment stage. Interestingly, their results showed that $E$. coli was not found in the fruit and edible plant parts. Irrigation method is said to greatly determine the level of contamination (Vergine et al., 2017). Similarly, wastewater generated from vegetable processing industry that underwent primary and secondary treatment stages was 
used for irrigation of vegetable plantation. Samples of water, soil, plant and vegetable crops were investigated for fecal indicators, $E$. coli and fecal enterococci. Their studies were carried out in two seasons. Fecal indicator level in secondary treated wastewater was found to be above permissible limit while a high level of $E$. coli was observed for tomato crop. Further, soil samples of one of the experimental seasons tested positive to Listeria monocytogenes. The microorganism of soil environment was also affected by irrigation. It was concluded that the pathogenic bacteria contamination in open field may not necessarily rest on the quality of irrigation water (Gomes, Costa, Quinta-Ferreira, \& Martins, 2017).

Disease outbreak based on RTEv contamination has been said to increase with about two hundred percent between 2009 and 2014 (Beneduce et al., 2017). Thus studies focusing on the microorganism (bacteria and viruses) as well as resistant organisms' presence in vegetables have been reported across Europe (Beneduce et al., 2017; Berthold-Pluta, Garbowska, Stefańska, \& Pluta, 2017; Terio et al., 2017), Africa (Ssemanda et al., 2017; Quansah, Kunadu, Saalia, DíazPerez, \& Chen, 2018), America (Byrne, Hofer, Vallim, \& Almeida, 2016; González, Cadona, Sanz, Bustamante, \& Sanso, 2017) and Asia (FaourKlingbeil, Murtada, Kuri, \& Todd, 2016; Wang, Qiao, Chen, Su, \& Zhu, 2015; Kim et al., 2015). Such microorganism contaminations have been traced to the following factors: contamination from pre- and post-harvest handling, Resistance of microbes to disinfectant method(s), quality of irrigation water, bad sanitation and lack of cleaning, lack of adequate information by workers within the processing industries and sales outlets, lack of adequate information to consumers, loose handling of wash water and inappropriate transportation and inadequate storage respectively.

Chlorination is the most employed disinfection method in RTEv industries (Ömez \& Kretzschmar, 2009), it offers economic advantage, it is efficient and easy to apply. This may however result in the formation of carcinogenic by products (Coroneo et al., 2017; Loan, Jacxsens, Kurshed, \& De Meulenaer, 2016) thus, campaign towards obtaining alternate disinfecting method(s) in the RTEv industries has been on the increase (Artés, Gómez, Aguayo, Escalona, \& ArtésHernández, 2009; Meireles, Giaouris, \& Simões, 2016). Wastewater generated from vegetable processing may contain huge volume of inactive pathogenic bacteria due to disinfection processes. However, reactivation of such bacteria once the disinfectant stress wares out is possible thus the reuse of such wastewater may lead to serious crop and environmental pollution. Worse of all is the existence of chlorine resistant bacteria in wastewater. Microbes can grow resistance to disinfection chemical/techniques via a shielding effect growth through background matrix as well as microbes encapsulation in or adhesion onto particle surface among others (Cherchi \& Gu, 2011). Resistance to chlorine is also said to be higher in gram positive bacteria compared with gram negative bacteria (Roy \& Ghosh, 2017).

Indeed, good attention should be paid to water reuse in closed agroindustrial firms to reduce or avoid the possibility of recycling pathogens within the system as well as breeding of resistant pathogens. Enough care should be taken to prevent resistant and reactivated pathogens from re-accessing the garden via irrigation water. Chlorine concentration as well as its periodic effect on crops should be given adequate attention. The drip system of irrigation which releases irrigation water directly to plant roots while avoiding contacts with crops is encouraged. Further wastewater treatment beyond the chlorination stage may help in either reduction or complete eradication of pathogenic organisms thus making agro-industrial wastewater safe for reuse.

\section{Domestic wastewater as water for irrigation}

One significant water source in agricultural irrigation is the domestic wastewater. Domestic wastewater consists of a range of hazardous materials alongside pathogenic microbes and amoeba (Cui et al., 2017). This category of wastewater has been identified as a major source of environmental deterioration. Domestic wastewater has been identified as a major source of pollution to natural water bodies and the environment at large. Particularly, eutrophication and proliferation of pathogenic microbes are few of the challenges posed on the water environment by domestic wastewater (Gao et al., 2017).

\subsection{Sporadic nature of domestic wastewater}

Domestic wastewater has a wide range of pollutants ranging from physically evident oil and grease, highly carcinogenic heavy metals, endocrine disruptive chemicals such as pharmaceutical and personal care product wastes to pathogenic microbes which threatens human health (Balkhair et al., 2016; Lees, Fitzsimons, Snape, Tappin, \& Combe, 2016). Other constituent of domestic wastewater are nutrient such as nitrogen and phosphorus, organic matters, high chemical oxygen demand generating energy of more than $130 \mathrm{~kJ} / \mathrm{g}$-COD (Latrach et al., 2018; Yang et al., 2018a; Zhang et al., 2018). Domestic wastewater may either be black or grey. Black water includes water from toilet, usually of high faecal and pathogen contamination (Tervahauta, Rani, Leal, Buisman, \& Zeeman, 2014) while grey water, on the other hand, is a combination of wastewater generated from other domestic activities such as laundry, bathing and dish washing (Al-Hamaiedeh \& Bino, 2010). Grey water may contain some pathogens and it is usually rich in soaps, surfactant and other personal care products waste. It is also characterized by a high tendency for contamination with non-metabolized antibiotics in the body which are discharge via human urinary activities.

Unfortunately, the rural dwellers in the developing nations readily irrigates using domestic wastewater without attention to their consequential effect on soil and water environment as well as cultivated crop (Keraita, Konradsen, Drechsel, \& Abaidoo, 2007; Abegunrin, Awe, Idowu, \& Adejumobi, 2016; Yue et al., 2017). Lack of knowledge of the consequential effects, economic challenges, inadequate planning, absence of environmental regulation and the un-enforcement of the same are some factors encouraging the use of untreated domestic wastewater for irrigation. Bioaccumulation of hazardous contaminants in crops may arise from the use of untreated wastewater for irrigation. This impact may vary depending on types of crop and irrigation methods. Hence, irrigation water that would be applied to crops which are eaten in their raw state should be completely free from pathogens (Balkhair et al., 2016; Chaoua, Boussaa, El Gharmali, \& Boumezzough, 2018).

\subsubsection{Reuse of domestic wastewater for irrigation: review of recent literature}

Coupled with other hazardous contaminants earlier itemized as domestic wastewater content, pathogenic amoebae has also been identified and reported (Cui et al., 2017). Several threats have been reported in vegetables in relation with irrigation using domestic wastewater either in their treated or raw forms.

A study which investigated the effects of bathroom and laundry water amongst others on two vegetables have been reported. These selected domestic wastewater was used to irrigate eggplant and spinach on a pre-planned plot. Although, plant growth was observed to increase with irrigation time, the leave area of the vegetables moderately grew when irrigated with bathroom and laundry wastewater as compared with other irrigation water sources. Since this study focused on increased soil fertility viz-a-viz crop productivity, threat posed by the use of such domestic wastewater was not reported (Abegunrin et al., 2016). Microbiological threats that accompany the use of treated domestic wastewater in irrigation of vegetables have been reported. Wastewater obtained after secondary treatment in a central city situated WWTP was used in this study. The $\mathrm{pH}$ as well as heavy metal concentration was reported to be within the acceptable range for wastewater reuse in irrigation. However, most biological disease agents gave higher count than the WHO recommendation. It was observed that increase in wastewater used in irrigation results in increase in bacteria count in 
vegetable crop. They concluded that the domestic wastewater used requires further treatment before its use in irrigation (Balkhair et al., 2016). Heavy metal content of raw sewage wastewater, soil and crops of a region in Morocco was investigated and reported. Selected eight vegetables commonly cultivated in the region was used for this study. Although the concentrations of most metals investigated were below permissible limits set by the international regulatory bodies with the exception of cadmium, the study was tagged important looking at the bioaccumulation and bioavailability possibilities of heavy metals. Investigations was carried out on the root, leaf and seed of each vegetable sample. While copper, zinc, lead and cadmium were found at high concentration in the soil samples, the investigated vegetables were mostly contaminated with cadmium and lead. They concluded that continuous consumption of such vegetable may result in heavy metals accumulation in human body with resultant health challenges (Chaoua et al., 2018). A similar study presented loading of heavy metals in soil and vegetables as well as its potential health implications. The wastewater used in this study went through the three wastewater treatment stages before its use in the irrigation of six common vegetables. Their results showed a low risk of soil pollution, all investigated metals were in concentration lower than the acceptable limit set by WHO. The potential health risk study indicates serious danger for children compared to adults with chromium contributing the highest health risk concerns (Qureshi, Hussain, Ismail, \& Khan, 2016).

Cao, Chen, Ma, Jia, \& Wang, 2016, presented a study suggesting a way out of metal bioaccumulation and metal associated health risks from vegetable consumption. Domestic and industrial wastewaters were used, four vegetables were studied, and the top as well as the subsurface soil were studied for the presence of heavy metals. Further, heavy metal bioaccumulation in soil and crops was also investigated on two sites viz an open field and within a greenhouse. The soil pollution was reported to be lowest for plant irrigated with domestic wastewater and cultivated within the greenhouse, while all studied soil were found highly contaminated with arsenic and cadmium. Vegetables under study were greatly contaminated irrespective of wastewaters used and cultivation modes. Although, level of contamination was lower in greenhouse and domestic water irrigated crops. Interestingly, the greenhouse cultivation system greatly reduced bioaccumulation of metals in vegetables (Cao et al., 2016).

Almuktar \& Scholz, 2015, presented microbial contamination of a vegetable grown with domestic wastewater treated by vertical flow wetlands. The microbial studies focused on total coliforms, E. Coli, faecal streptococcus spp, faecal coliforms and salmonella spp. The domestic wastewater used for irrigation in this study was found to have high total coliform contamination. Soil contamination by $E$. Coli was highest from wastewater with preliminary treatment from plant whose heights are greater or equal to $50 \mathrm{~cm}$. They concluded that the overall contamination harvested was less than 5\% (Almuktar \& Scholz, 2015). The mineral content and biological contamination of soil and crops have been investigated and documented by Almuktar \& Scholz, 2016. Mineral content associated more with the organic content than inorganic content. The investigated metals were not detectable in vegetable samples. Although the water used for irrigation had microbial contamination, crops from plants with height of $50 \mathrm{~cm}$ and above were not contaminated with microbes. Crops irrigated with raw wastewater were reported to be highly contaminated with streptococcus and salmonella spp. They concluded that high nutrient supply resulted in low harvest of vegetable (Almuktar \& Scholz, 2016). Another study which used two generations of chilli propagation using domestic wastewater for irrigation has been reported. The domestic wastewater was treated by vertical flow wetlands methods. The study focused on reused water suitability, effects and impacts of the volume of wastewater used in cultivation among others. They found out that coliforms and nutrients level of the irrigation water was higher than the threshold limits. Fruits with better quality were obtained from plants which receives more irrigation water (Almuktar, Abed, \& Scholz, 2017). Urbano, Mendonc,
Bastos, \& Souza, 2017 also reported the possible effects of treated domestic effluent on the properties of soil as well as lettuce. In their study conducted in a greenhouse, two water sources viz partial conventional fertilized treated wastewater and conventionally fertilized drinking water were used. The fertilized drinking water recorded BOD far greater than the recommended concentration for irrigation water while the total coliform for the two irrigation water was reported to be about twice the threshold limit expected for irrigation water for vegetables. Soil structure was not affected by the fertilized drinking water, however the two water used for irrigation results in decrease in soil organic matters. Although, the cultivated lettuce was found to be deficient in some nutrients, no physical reflection was seen for these deficiencies (Urbano et al., 2017).

One component of domestic wastewater is oil. A study which reported the effects of oil spill among others on the recycled wastewater suitability in sweet pepper and chilli propagation is also of interest. Their findings indicate that presence of hydrocarbons in wastewater may lead to low yield of cultivated vegetables (Almuktar, Scholz, AlIsawi, \& Sani, 2015). Raw, partially treated and tertiary treated municipal wastewater were used for the irrigation of a vegetable (artichoke). Interest was placed on microbiological contributions to the soil and plant as well as safety of the vegetable. Partially and tertiary treated wastewater were reported to be rich in nutrient and organic matters consequently results in better yield of cultivated vegetables. E. coli content of the partially treated wastewater was found far higher than the threshold limit while tertiary treatment brought this low. Partially treated wastewater contained salmonella spp. E. coli were present in soil while very few samples showed presence of salmonella. Very low E. coli were found in crops in general. It was concluded that the microbial quality of crops were not affected (Gatta et al., 2016).

From the fore going review, pollutants such as heavy metals, which have serious carcinogenic characteristic also accompany domestic wastewater. Hence, the treatment techniques employed in domestic wastewater will greatly reduce current threats to the health of the consumers of irrigated crops. For instance, primary, secondary and effective tertiary treatment will greatly reduce or completely remove the major microbial risk concerns that comes with RTEv consumption.

\section{Combating poverty, hunger and malnutrition: ignorance, birthing a greater damage}

The African continent with a fast growing population lack the basic needs for the required quality life. Food takes the lead in the basic needs of man. SSA has the second largest number of hungry people in the world (FAO, 2013). Hunger and malnutrition are indicators of poverty, this is a major challenge in SSA. Starchy food which lacks required nutrient forms the main diet in SSA. Since food security now captures nutrition and this is being strongly driven globally, serving common starchy foods with vegetables is a means of augmenting nutrition for common black man.

Interestingly, Nigeria has a rich base of traditional vegetables that are either eaten raw or served with main dish. Vegetable types vary across various ethnic groups in Nigeria (Aregheore, 2012). These vegetables are mostly cultivated amidst low income earners as food, food substitutes and supplements such as iron supply for pregnant women as well as a boost of income (Aworh, 2015; Ezebilo, 2010; Ferdous, Datta, Anal, Anwar, \& Khan, 2016). Thus, vegetable exist within residential buildings across Nigeria.

Irrigation is not popular in Nigeria, currently farming activities mainly depends on rainfall (Olayide \& Alabi, 2018). However, since these products are required all year round, domestic wastewater is majorly used in a crude irrigation technique. This domestic wastewater may be a mixture of black and grey water and many local farmers and consumers are ignorant of the health implications of domestic wastewater irrigation (Mojid, Wyseure, Biswas, \& Hossain, 2010; Qadir et al., 2010). Previous report stated that some vegetables sold in some 


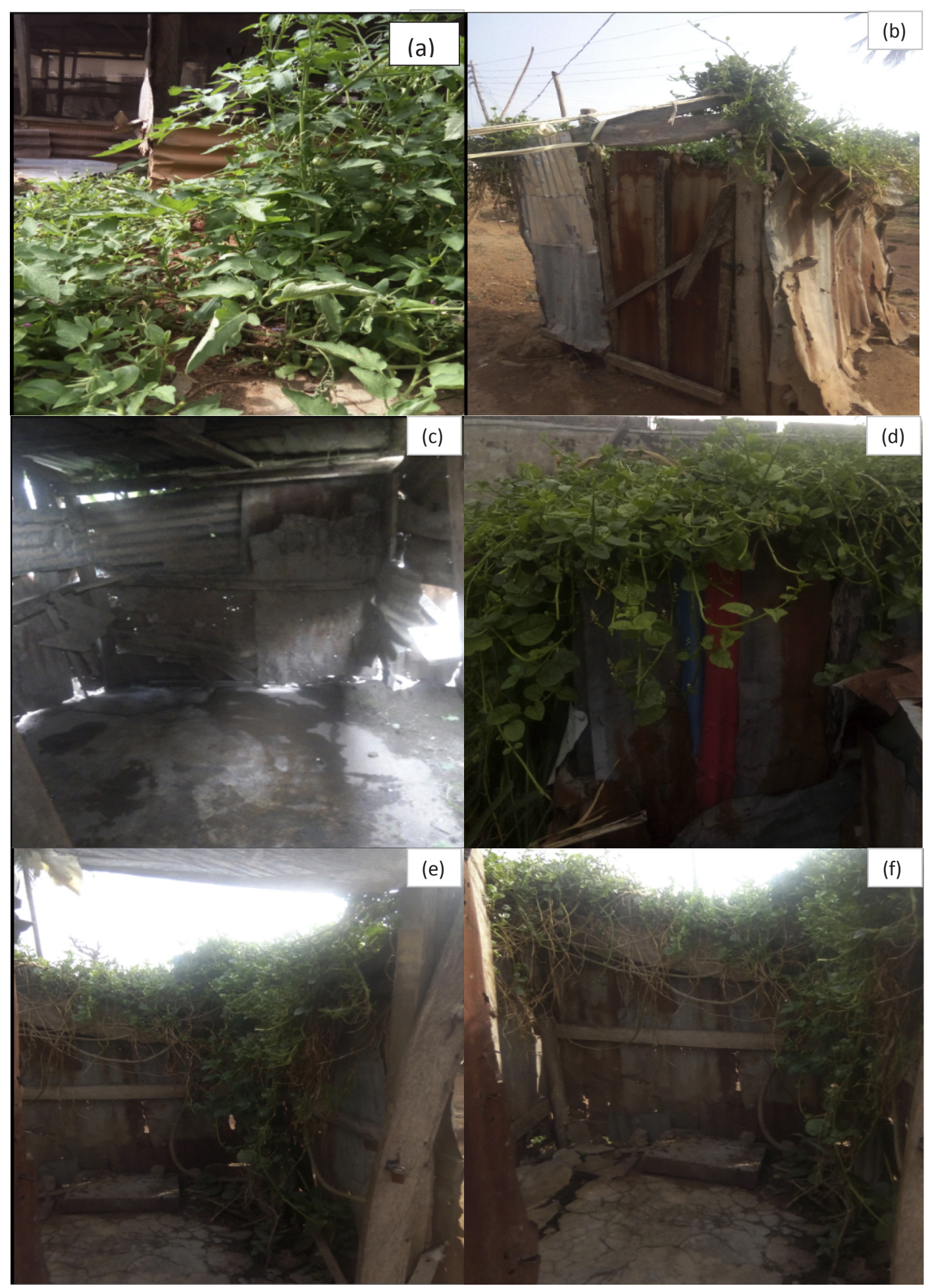

Fig. 3a. Solanum lycopersicum (Source: Author); (b) Typical local bathroom outside (Source: Authors); (c) Typical local bathroom inside (Source: Authors); (d) Flourishing B. alba plant continuously irrigated with grey/black water (Source: Authors); (e and f) Local bathroom overgrown with B. alba plant (Source: Authors).

Nigerian markets are contaminated with helminthes (Adamu, Adamu, \& Mohammed, 2012; Adenusi, Abimbola, \& Adewoga, 2015; Maikai et al., 2010). The source of which could be traced to the use of wastewater from human and animals. Most vegetable gardens are irrigated following crude ways in which flowing waters from bathrooms are channeled directly to the vegetable gardens. In order to fertilize vegetables, practices such as direct planting behind toilets are common. These practices are considered as cheap alternative to inorganic fertilizer, real irrigation practice as well as convenient (Agele, Adeyemo, \& Famuwagun, 2011; Oyedeji, Animasaun, Bello, \& Agboola, 2014; Contreras et al., 2017). Common vegetables cultivated in this manner are Indian spinach (Basella alba), fluted pumpkin (Telfeira occidentalis), Catholic vegetable (Jatropha tanjorensis) and water leaf (Talinum fruticosum). Fig. 3a and b represents a typical cultivation techniques of afore mentioned vegetables in Southwestern Nigeria. 


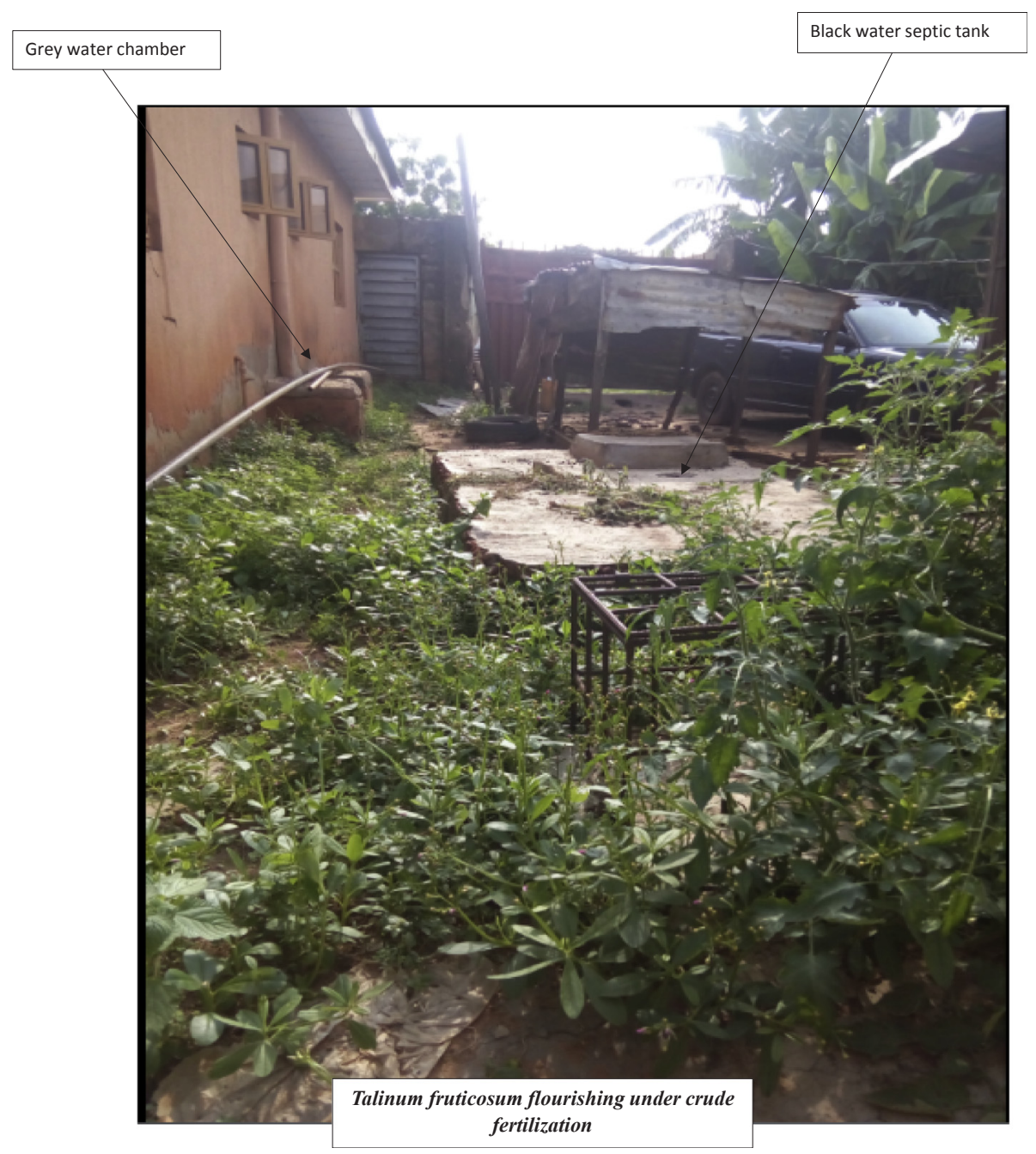

Fig. 3b. Crude fertilization technique (various vegetable cultivation around grey water chamber and black water septic tank) (Source: Authors).

\subsection{The dilemma of irrigation with black/grey water}

Emerging contaminants (ECs) is currently a serious concern to environmentalists. Although, this knowledge is not common in the developing nations and most developed nations still lack regulations concerning ECs (Gogoi et al., 2018; Sophia et al., 2018). The widely used pharmaceuticals and personal care products (PPCp) belongs to the emerging contaminant group (Wilkinson, Hooda, Barker, Barton, \& Swinden, 2017; Zhao et al., 2018). Antibiotic is characterized with incomplete metabolism within human body thus, it is abundantly discharged with wastes into the environment (Gomes, Costa, QuintaFerreira, \& Martins, 2017; Mandaric et al., 2017), both antibiotics and personal care product form components of municipal wastewater (Balakrishna, Rath, Praveenkumarreddy, Guruge, \& Subedi, 2017; Wang, Huang, \& Wei, 2018). PPCp exists in the environment at a very low concentration (Richardson et al., 2017), they can however be a source of serious health concerns such as drug resistance development, endocrine disruption and carcinogenicity (Bai et al., 2018; Inyinbor, Bello, Fadiji, \& Inyinbor, 2018).

The presence of PPCp in various environmental samples such as wastewater, slugde and receiving river water and sediment (Huber et al., 2016), drinking water (Lin, Yu, \& Chen, 2016), urban stream (Tamura et al., 2017), drinking water source (Dodgen et al., 2017), WWTP and environmental water (Archer, Petrie, Kasprzyk-Hordern, \& Wolfaardt, 2017), soil (Ma et al., 2018) as well as surface and ground water (Yang et al., 2018b) have been reported. While humans may become exposed to these threats through interactions with various environmental samples, bioaccumulation of PPCp in plants and other living/aquatic organisms which serves as food for man is of major concern (Picó, Alfarham, \& Barcel, 2017). PPCp can bio accumulate in plants thus affecting plants micro biota as well as organisms depending on such plants for food. Thus, pharmaceuticals may become a part of the food chain (Bartrons \& Peñuelas, 2017; Al-Farsi et al., 2017). Bioaccumulation of PPCp in vegetables which are eaten raw or with slight cooking can pose serious health concerns. Aquatic organisms such as mussels, tad poles and fishes may also be negatively affected by PPCp (Wu et al., 2013). Previous report had shown uptake and bioaccumulation of four PPCPs in lettuce (Dodgen, Li, Parker, \& Gan, 2013), accumulation of twenty PPCps in lettuce, spinach, cucumber and pepper (Wu, Ernst, Conkle, \& Gan, 2013), uptake of eight emerging organic contaminants by lettuce (Aparicio, Martín, Abril, Santos, \& Alonso, 2018) and PPCps bioaccumulation in wild fishes obtained from two rivers in China (Yao et al., 2018).

The existence of PPCps and other emerging contaminants in the environment is certain and their bioaccumulation ability in vegetables and other crops have also been established. Personal care products are used in almost all homes and the use of pharmaceuticals, particularly antibiotics here in Nigeria have loose restriction. Hence, PPCps release into the environment here is certain, constant and continuous. It readily comes with domestic wastewater. Sadly, the practice of crude irrigation is without adequate knowledge of the presence and impact of the aforementioned dangerous pollutant both to the environment and the 
irrigated crops. The uptake of PPCp by vegetables depend on type of PPCp as well as the irrigation system. Both root and folia uptake of PPCp is possible (Bhalsod et al., 2018). Crude irrigation/fertilization techniques used for various vegetables cultivation across southwestern Nigeria (Fig. 3a and b) present a source of serious PPCp contamination, accumulation as well as threats to humans consuming them. A study which used two endocrine disruptive chemicals has reported that $B$. alba root system makes transpiration in this vegetable to be very vigorous (Qiu et al., 2016). One great concern is the antibiotic resistant bacteria breeding and antibiotic resistant gene development. This can lead to serious difficulties in handling patients exposed to such vegetables. Vegetables are known to easily harbor and spread microorganisms to its consumers thus cultivation of vegetable in such a manner which utilizes grey/black wastewater in a crude irrigation system therefore should be abolished.

\subsection{Challenges and future prospects}

Crop contamination depends largely on the type of irrigation water, modes of irrigation, crop interaction with wide lives or other animals, types of contaminants and its uptake pattern. Contaminant accumulation however depends on the types of crop. For instance, knowledge of overhead system of irrigation presents greater danger when compared with drip or surface irrigation. Although, surface irrigation may also result in accumulation of pollutants in soil and subsequent transfer of these pollutants to plants. This review of literature has opened up various ways in which vegetables can be contaminated. It also highlight a crude irrigation technique with a discussion on their possible effect(s). This crude irrigation technique uses majorly grey water. Emerging contaminants, a group which pharmaceuticals and personal care products belong is of a worldwide concern. Antibiotics and PPCps wastes are ready component of grey water particularly in places where antibiotic consumption is high and their usage is without proper checks. Access to antibiotics in the developing nations is very easy. Antibiotics are readily purchased with or without prescription over-the-counter chemical shop, in drug stores, hospitals as well as road side stalls. Antibiotics are not completely metabolized in the body. Huge percentage of the consumed antibiotic are excreted through urine or faeces. Antibiotics not metabolized, when excreted form a component of grey water. This poses threat by (1) Breeding antibiotic resistant microbes; (2) Resistant microbes spreading resistant across bacteria by gene transfer (3) Accumulation of PPCps in vegetables irrigated with such grey water. Hence, this ignorant practice of crude irrigation should be checked.

Serious vegetable contamination results when contaminated water is used in irrigation and when vegetables keep permanent contact with contaminated soil, this is the case in the described crude irrigation technique. The practice of vegetable cultivation around residencies may never stop in the developing nations. This is one way of addressing our nutritional challenges and alleviating poverty. This study therefore may serve as a tool for policy development and enlightenment among rural dwellers.

While bioaccumulation of emerging contaminants in crops particularly vegetable is a subject of discuss and a concern globally, such studies are scarce in developing nations and to the best of our knowledge has not been undertaken here in Nigeria. This may be due to lack of required equipment and unavailability of required finance. To vividly expose the danger of crude irrigation technique, studies on its consequential effects and associated health challenges will be required.

\section{Conclusion}

The global call to increase vegetable consumption for nutritional benefits as well as health advantages led to massive RTEv production. Clean production of RTEv requires huge volume of water and as well generate large volumes of wastewater. Sustainability in RTEv industries therefore require water recirculation within the system. We call for great caution in the reuse of RTEv wastewater for vegetable irrigation purposes due to some of its dangerous component such as carcinogenic by-product of chlorine, reactivated microbes and resistant microbes which could have serious negative impact on the irrigated crop, human and the environment at large. The use of PAA as an alternative to chlorine was identified as possible solution to carcinogenic by-product and total microbe inactivation. Sound knowledge of irrigation water types, extent of treatment/required treatment as well as irrigation system techniques will reduce or completely eradicate possible dangers. Effective wastewater treatment may therefore generate required clean and sustainable water supply. Drip irrigation techniques is also preferable to overhead irrigation in vegetable cultivation.

Poverty, hunger and malnutrition ravaging the black race can be addressed through agriculture. Rain fed agriculture however cannot proffer required solution hence the need to embrace irrigation. Wastewater reuse in crop irrigation has been identified as suitable as well as required particularly where intensive agriculture is needed for transformation and poverty alleviation. This will ensure sustainable production required to address and alleviate poverty. Efforts towards all year round vegetable production via crude irrigation however may do more damage than address the previous. The easy propagation of vegetables has made it a choice for food supplement among rural dwellers and low income earners in the developing nations. However, the crude irrigation method which barely exposes vegetables to pathogenic microbes, resistant microbes and endocrine disruptive chemicals makes it a serious threat. Since vegetables have high tendency to harbor and spread pathogenic and resistant microbes. Their cultivation should be with proper knowledge and utmost care in order to ensure clean production. From the fore-going, policy makers and government officials saddled with the environmental, food and health issues responsibilities should act adequately to advocate the danger of crude irrigation techniques. Policy development that will eradicate crude irrigation technique should also be established.

\section{References}

Abegunrin, T. P., Awe, G. O., Idowu, D. O., \& Adejumobi, M. A. (2016). Impact of wastewater irrigation on soil physico-chemical properties, growth and water use pattern of two indigenous vegetables in Southwest Nigeria. Catena, 139, 167-178.

Adamu, N. B., Adamu, J. Y., \& Mohammed, D. (2012). Prevalence of helminth parasites found on vegetables sold in Maiduguri, Northeastern Nigeria. Food Control, 25, 23-26.

Adenusi, A. A., Abimbola, W. A., \& Adewoga, T. O. S. (2015). Human intestinal helminth Contamination in pre-washed, fresh vegetables for sale in major markets in Ogun State, southwest Nigeria. Food Control, 50, 843-849.

Agele, S. O., Adeyemo, A. J., \& Famuwagun, I. B. (2011). Agricultural wastes and mineral fertilizer on soil and plant nutrient status, growth and yield of tomato. Archives of Agronomy and Soil Science, 57, 91-104.

Al-Farsi, R. S. A., Al-Busaidi, M., \& Choudri, B. S. (2018). Translocation of pharmaceuticals and personal care products (PPCPs) into plant tissues: A review, emerging contaminants. 2018 https://doi.org/10.1016/j.emcon.2018.02.001.

Al-Hamaiedeh, H., \& Bino, M. (2010). Effect of treated grey water reuse in irrigation on soil and plants. Desalination, 256, 115-119.

Alegbeleye, O. O., Singleton, I., \& Sant'Ana, A. S. (2018). Sources and contamination routes of microbial pathogens to fresh produce during field cultivation: A review. Food Microbiology, 73, 177-208.

Allende, A., Truchado, P., Lindqvist, R., \& Jacxsens, L. (2018). Quantitative microbial exposure modelling as a tool to evaluate the impact of contamination level of surface irrigation water and seasonality on fecal hygiene indicator E. coli in leafy green production. Food Microbiology, 75, 82-89.

Almuktar, S. A. A. A. N., Abed, S. N., \& Scholz, M. (2017). Recycling of domestic wastewater treated by vertical-flow wetlands for irrigation of two consecutive Capsicum annuum generations. Ecological Engineering, 107, 82-98.

Almuktar, S. A. A. A. N., \& Scholz, M. (2015). Microbial Contamination of Capsicum annuum irrigated with recycled domestic wastewater treated by vertical-flow wetlands. Ecological Engineering, 82, 404-414.

Almuktar, S. A. A. A. N., \& Scholz, M. (2016). Mineral and biological contamination of soil and Capsicum annuum irrigated with recycled domestic wastewater. Agricultural Water Management, 167, 95-109.

Almuktar, S. A. A. A. N., Scholz, M., Al-Isawi, R. H. K., \& Sani, A. (2015). Recycling of domestic wastewater treated by vertical-flow wetlands for irrigating Chillies and Sweet Peppers. Agricultural Water Management, 149, 1-22.

Anese, M., Maifreni, M., Bot, F., Bartolomeoli, I., \& Nicoli, M. C. (2015). Power ultrasound 
decontamination of wastewater from fresh-cut lettuce washing for potential water recycling. Innovative Food Science \& Emerging Technologies, 32, 121-126.

Aparicio, I., Martín, I., Abril, C., Santos, J. L., \& Alonso, E. (2018). Determination of household and industrial chemicals, personal care products and hormones in leafy and root vegetables by liquid chromatography-tandem mass spectrometry. Journal of Chromatography A, 1533, 49-56.

Archer, E., Petrie, B., Kasprzyk-Hordern, B., \& Wolfaardt, G. M. (2017). The fate of pharmaceuticals and personal care products (PPCPs), endocrine disrupting contaminants (EDCs), metabolites and illicit drugs in a WWTW and environmental waters. Chemosphere, 174, 437-446.

Aregheore, E. M. (2012). Nutritive value and inherent anti-nutritive factors in four indigenous edible leafy vegetables in human nutrition in Nigeria: A review. Journal of Food Resources Science, 1, 1-14.

Arouna, A., Lokossou, J. C., Wopereis, M. C. S., Bruce-Oliver, S., \& Roy-Macauley, H. (2017). Contribution of improved rice varieties to poverty reduction and food security in sub- Saharan Africa. Global Food Security, 14, 54-60.

Artés, F., Gómez, P., Aguayo, E., Escalona, V., \& Artés-Hernández, F. (2009). Sustainable sanitation techniques for keeping quality and safety of fresh-cut plant commodities. Postharvest Biology and Technology, 51, 287-296.

Aworh, O. C. (2015). Promoting food security and enhancing Nigeria's small farmers' income through value-added processing of lesser-known and under-utilized indigenous fruits and vegetables. Food Research International, 76, 986-991.

Bahram-Parvar, M., \& Lim, L. (2018). Fresh-cut onion: A review on processing, health benefits, and shelf-life. Comprehensive Reviews in Food Science and Food Safety, 17, 290-308.

Bai, X., Lutz, A., Carrol, R., Keteles, K., Dahlin, K., Murphy, M., et al. (2018). Occurrence, distribution, and seasonality of emerging contaminants in urban watersheds. Chemosphere, 200, 133-142.

Balakrishna, K., Rath, A., Praveenkumarreddy, Y., Guruge, K. S., \& Subedi, B. (2017). A review of the occurrence of pharmaceuticals and personal care products in Indian water bodies. Ecotoxicology and Environmental Safety, 137, 113-120.

Balkhair, K. S. (2016). Microbial contamination of vegetable crop and soil profile in arid regions under controlled application of domestic wastewater. Saudi Journal of Biological Sciences, 23, 83-92.

Bartrons, M., \& Peñuelas, J. (2017). Pharmaceuticals and personal-care products in plants. Trends in Plant Science, 22, 194-203.

Beneduce, L., Gatta, G., Bevilacqua, A., Libutti, A., Tarantino, E., Bellucci, M., et al. (2017). Impact of the reusing of food manufacturing wastewater for irrigation in a closed system on the microbiological quality of the food crops. International Journal of Food Microbiology, 260, 51-58.

Berthold-Pluta, A., Garbowska, M., Stefańska, I., \& Pluta, A. (2017). Microbiological quality of selected ready-to-eat leaf vegetables, sprouts and non-pasteurized fresh fruit-vegetable juices including the presence of Cronobacter spp. Food Microbiology, $65,221-230$.

Bhalsod, G. D., Chuang, Y., Jeon, S., Gui, W., Li, H., Ryser, E. T., et al. (2018). Uptake and accumulation of pharmaceuticals in overhead- and surface-irrigated greenhouse lettuce. Journal of Agricultural and Food Chemistry. https://doi.org/10.1021/acs.jafc $7 \mathrm{~b} 04355$.

Brookie, K. L., Mainvil, L. A., Carr, A. C., Vissers, M. C. M., \& Conner, T. S. (2017). The development and effectiveness of an ecological momentary intervention to increase daily fruit and vegetable consumption in low-consuming young adults. Appetite, 108, $32-41$.

Byrne, V. V., Hofer, E., Vallim, D. C., \& Almeida, R. C. C. (2016). Occurrence and antimicrobial resistance patterns of Listeria monocytogenes isolated from vegetables. Brazilian Journal of Microbiology, 47, 438-443.

Caicedo, C., Rosenwinkel, K. H., Exner, M., Verstraete, W., Suchenwirth, R., Hartemann, P., et al. (2019). Legionella occurrence in municipal and industrial wastewater treatment plants and risks of reclaimed wastewater reuse: Review. Water Research, $149,21-34$.

Cao, C., Chen, X., Ma, Z., Jia, H., \& Wang, J. (2016). Greenhouse cultivation mitigates metal- ingestion-associated health risks from vegetables in wastewater-irrigated agro ecosystems. The Science of the Total Environment, 560 -561, 204-211.

Caradonna, T., Marangi, M., Chierico, F. D., Ferrari, N., Reddel, S., Bracaglia, G., et al. (2017). Detection and prevalence of protozoan parasites in ready-to-eat packaged salads on sale in Italy. Food Microbiology, 67, 67-75.

Castro-Ibáñez, I., Gil, M. I., \& Allende, A. (2017). Ready-to-eat vegetables: Current problems and potential solutions to reduce microbial risk in the production chain. LWTFood Science and Technology, 85, 284-292.

Chang, J., Lee, W., \& Yoon, S. (2017). Energy consumption and associated greenhouse gas emissions in operation phases of urban water reuse system in Korea. Journal of Cleaner Production, 141, 728-736.

Chaoua, S., Boussaa, S., El Gharmali, A., \& Boumezzough, A. (2018). Impact of irrigation with wastewater on accumulation of heavy metals in soil and crops in the region of Marrakech in Morocco. Journal of the Saudi Society of Agricultural Sciences. https:// doi.org/10.1016/j.jssas.2018.02.003.

Chen, Z., Yu, T., Ngo, H. H., Lu, Y., Li, G., Wu, Q., et al. (2018). Assimilable organic carbon (AOC) variation in reclaimed water: Insight on biological stability evaluation and control for sustainable water reuse. Bioresource Technology, 254, 290-299.

Cherchi, C., \& Gu, A. Z. (2011). Effects of bacteria growth stage on resistance to Chlorine disinfection. Water Science and Technology, 64, 7-13.

Conidi, C., Cassano, A., \& Garcia-Castello, E. (2014). Valorization of artichoke wastewaters by integrated membrane process. Water Research, 48, 363-374.

Contreras, J. D., Meza, R., Siebe, C., Rodríguez-Dozal, S., López-Vidal, Y. A., CastilloRojas, G., et al. (2017). Health risks from exposure to untreated wastewater used for irrigation in the mezquital valley, Mexico: A 25-year update. Water Research, 123, $834-850$
Cornia, G. A., Deotti, L., \& Sassi, M. (2016). Sources of food price volatility and child malnutrition in Niger and Malawi. Food Policy, 60, 20-30.

Coroneo, V., Carraro, V., Marras, B., Marrucci, A., Succa, S., Meloni, B., et al. (2017) Presence of Trihalomethanes in ready-to-eat vegetables disinfected with chlorine. Food Additives \& Contaminants: Part A, 34, 2111-2117.

Cui, B., Luo, J., Jin, D., Jin, B., Zhuang, X., \& Bai, Z. (2017). Investigating the bacterial community and amoebae population in rural domestic wastewater reclamation for irrigation. Journal of Environmental Sciences, 70, 97-105.

Damalas, C. A., \& Khan, M. (2017). Pesticide use in vegetable crops in Pakistan: Insights through an ordered probit model. Crop Protection, 99, 59-64.

Dodgen, L. K., Kelly, W. R., Panno, S. V., Taylor, S. J., Armstrong, D. L., Wiles, K. N., et al. (2017). Characterizing pharmaceutical, personal care product, and hormone contamination in a karst aquifer of southwestern Illinois, USA, using water quality and stream flow parameters. The Science of the Total Environment, 578, 281-289.

Dodgen, L. K., Li, J., Parker, D., \& Gan, J. J. (2013). Uptake and accumulation of four PPCP/EDCs in two leafy vegetables. Environmental Pollution, 182, 150-156.

Elgallal, M., Fletcher, L., \& Evans, B. (2016). Assessment of potential risks associated with chemicals in wastewater used for irrigation in arid and semiarid zones: A review. Agricultural Water Management, 177, 419-431.

Ezebilo, E. E. (2010). Conservation of a leafy vegetable important for communities in the Nigerian rainforest. Forest Ecology and Management, 259, 1660-1665.

FAO (2013). The state of food and agriculture.

FAO (Food and Agriculture Organization) (2009). Declaration of the world summit on food security, Rome.

Faour-Klingbeil, D., Murtada, M., Kuri, V., \& Todd, E. C. D. (2016). Understanding the routes of contamination of ready-to-eat vegetables in the Middle East. Food Control, 62, 125-133.

Ferdous, Z., Datta, A., Anal, A. K., Anwar, M., \& Khan, A. S. M. M. R. (2016). Development of home garden model for year round production and consumption for improving resource-poor household food security in Bangladesh. NJAS-Wageningen. Journal of Life Sciences, 78, 103-110.

Gao, Y., Wang, C., Zhang, W., Di, P., Yi, N., \& Chen, C. (2017). Vertical and horizontal assemblage patterns of bacterial communities in a eutrophic river receiving domestic wastewater in southeast China. Environmental Pollution, 230, 469-478.

Gatta, G., Libutti, A., Beneduce, L., Gagliardi, A., Disciglio, G., Lonigro, A., et al. (2016). Reuse of treated municipal wastewater for globe artichoke irrigation: Assessment of effects on morpho-quantitative parameters and microbial safety of yield. Scientia Horticulturae, 213, 55-65.

Gatta, G., Libutti, A., Gagliardi, A., Beneduce, L., Brusetti, L., Borruso, L., et al. (2015). Treated agro-industrial wastewater irrigation of tomato crop: Effects on qualitative/ quantitative characteristics of production and microbiological properties of the soil. Agricultural Water Management, 149, 33-43.

Ghimpusan, M., Nechifor, G., Nechifor, A., Dima, S., \& Passeri, P. (2017). Case studies on the physical-chemical parameters' variation during three different purification approaches destined to treat wastewaters from food industry. Journal of Environmental Management, 203, 811-816.

Gogoi, A., Mazumder, P., Tyagi, V. K., Chaminda, G. G. T., An, A. K., \& Kumar, M. (2018). Occurrence and fate of emerging contaminants in water environment: A review. Groundwater for Sustainable Development, 6, 169-180.

Gomes, J., Costa, R., Quinta-Ferreira, R. M., \& Martins, R. C. (2017). Application of ozonation for pharmaceuticals and personal care products removal from water. The Science of the Total Environment, 586, 265-283.

Gómez-López, V. M., Gobet, J., Selma, M. V., Gil, M. I., \& Allende, A. (2013). Operating conditions for the electrolytic disinfection of process wash water from the fresh-cut industry contaminated with E. coli o157:H7. Food Control, 29, 42-48.

González, J., Cadona, J. S., Sanz, M., Bustamante, A. V., \& Sanso, A. M. (2017). Molecular characterization of diarrheagenic Escherichia coli isolated from vegetables in Argentina. International Journal of Food Microbiology, 261, 57-61.

Heaton, J. C., \& Jones, K. (2008). Microbial contamination of fruit and vegetables and the behaviour of enteropathogens in the phyllosphere: A review. Journal of Applied Microbiology, 104, 613-626.

Huber, S., Remberger, M., Kaj, L., Schlabach, M., Jörundsdóttir, H.Ó., Vester, J., et al, A first screening and risk assessment of pharmaceuticals and additives in personal care products in waste water, sludge, recipient water and sediment from Faroe Islands, Iceland and Greenland. The Science of the Total Environment. 562, 13-25.

Inyinbor, A. A., Bello, O. S., Fadiji, A. E., \& Inyinbor, H. E. (2018). Threats from antibiotics: A serious environmental concern. Journal of Environmental Chemical Engineering, 6, 784-793.

Jiménez-Tototzintle, M., Oller, I., Hernández-Ramírez, A., Malato, S., \& Maldonado, M. I. (2015). Remediation of agro-food industry effluents by biotreatment combined with supported TiO2/H2O2 solar photocatalysis. Chemical Engineering Journal, 273 205-213.

Keraita, B., Konradsen, F., Drechsel, P., \& Abaidoo, R. C. (2007). Effect of low-cost irrigation methods on microbial contamination of lettuce irrigated with untreated wastewater. Tropical Medicine and International Health, 12, 15-22.

Kim, H., Chon, J., Kim, Y., Kim, D., Kim, M., \& Seo, K. (2015). Prevalence and characterization of extended-spectrum- $\beta$-lactamase producing Escherichia coli and Klebsiella pneumonia in ready-to-eat vegetables. International Journal of Food Microbiology, 207, 83-86.

Kramer, C. V., \& Allen, S. (2015). Malnutrition in developing countries. Paediatrics and Child Health, 25(9), 422-427.

Latrach, L., Ouazzani, N., Hejjaj, A., Mahi, M., Masunaga, T., \& Mandi, L. (2018). Twostage vertical flow multi-soil-layering (MSL) technology for efficient removal of coliforms and human pathogens from domestic wastewater in rural areas under arid climate. International Journal of Hygiene and Environmental Health, 221, 64-80.

Lees, K., Fitzsimons, M., Snape, J., Tappin, A., \& Combe, S. (2016). Pharmaceuticals in 
soils of lower income countries: Physico-chemical fate and risks from wastewater irrigation. Environment International, 94, 712-723.

Lehto, M., Sipilä, I., Alakukku, L., \& Kymäläinen, H. (2014). Water consumption and wastewaters in fresh-cut vegetable production. Agricultural and Food Science, 23, 246-256.

Libutti, A., Gatta, G., Gagliardi, A., Vergine, P., Pollice, A., Beneduce, L., et al. (2018). Agro-industrial wastewater reuse for irrigation of a vegetable crop succession under Mediterranean conditions. Agricultural Water Management, 196, 1-14.

Lin, T., Yu, S., \& Chen, Y. (2016). Occurrence, removal and risk assessment of pharmaceutical and personal care products (PPCPs) in an advanced drinking water treatment plant (ADWTP) around Taihu Lake in China. Chemosphere, 152, 1-9.

Liu, J., Liu, Q., \& Yang, H. (2016). Assessing water scarcity by simultaneously considering environmental flow requirements, water quantity, and water quality. Ecological Indicators, 60, 434-441.

Loan, H. N. B., Jacxsens, L., Kurshed, A. A. M., \& De Meulenaer, B. (2016). 3Chlorotyrosine formation in ready-to-eat vegetables due to hypochlorite treatment and its dietary exposure and risk assessment. Food Research International, 90, 186-193.

Maffei, D. F., Alvarenga, V. O., Sant'Ana, A. S., \& Franco, B. D. G. M. (2016). Assessing the effect of washing practices employed in Brazilian processing plants on the quality of ready-to-eat vegetables. LWT-Food Science and Technology, 69, 474-481.

Maikai, B. V., Elisha, I. A., \& Baba-Onoja, E. B. T. (2012). Contamination of vegetables sold in markets with helminth eggs in Zaria metropolis, Kaduna State, Nigeria. Food Control, 28, 345-348.

Ma, L., Liu, Y., Zhang, J., Yang, Q., Li, G., \& Zhang, D. (2018). Impacts of irrigation water sources and geochemical conditions on vertical distribution of pharmaceutical and personal care products (PPCPs) in the vadose zone soils. The Science of the Total Environment, 626, 1148-1156.

Mandaric, L., Diamantini, E., Stella, E., Cano-Paoli, K., Valle-Sistac, J., Molins-Delgado, D., et al. (2017). Contamination sources and distribution patterns of pharmaceuticals and personal care products in Alpine rivers strongly affected by tourism. The Science of the Total Environment, 590-591, 484-494.

Matsumura, E. M., \& Mierzwa, J. C. (2008). Water conservation and reuse in poultry processing plant- A case study. Resources, Conservation and Recycling, 52, 835-842.

Mechelen, C. V., Dutoit, T., \& Hermy, M. (2015). Adapting green roof irrigation practices for a sustainable future: A review. Sustainable Cities and Society, 19, 74-90.

Meireles, A., Giaouris, E., \& Simões, M. (2016). Alternative disinfection methods to chlorine for use in the fresh-cut industry. Food Research International, 82, 71-85.

Mir, S. A., Shah, M. A., Mir, M. A., Dar, D. N., Greiner, R., \& Roohinejad, S. (2018). Microbiological contamination of ready-to-eat vegetable salads in developing countries and potential solutions in the supply chain to control microbial pathogens. Food Control, 85, 235-244.

Mojid, M. A., Wyseure, G. C. L., Biswas, S. K., \& Hossain, A. B. M. Z. (2010). Farmers' perceptions and knowledge in using wastewater for irrigation at twelve peri-urban areas and two sugar mill areas in Bangladesh. Agricultural Water Management, 98, 79-86.

Mritunjay, S. K., \& Kumar, V. (2015). Fresh farm produce as a source of pathogens: A review. Research Journal of Environmental Toxicology, 9, 59-70.

Muñoz, I., Gómez-Ramos, M. J., Agüera, A., García-Reyes, J. F., Molina-Díaz, A., \& Fernández- Alba, A. R. (2009). Chemical evaluation of contaminants in wastewater effluents and the environmental risks of reusing effluents in agriculture. Trends in Analytical Chemistry, 28, 676-694.

Mutambara, S., Darkoh, M. B. K., \& Atlhopheng, J. R. (2016). A comparative review of water management sustainability challenges in smallholder irrigation schemes in Africa and Asia. Agricultural Water Management, 171, 63-72.

Nahim-Granados, S., Sánchez Pérez, J. A., \& Polo-Lopez, M. I. (2018). Effective solar processes in fresh-cut wastewater disinfection: Inactivation of pathogenic E. coli O157:H7 and Salmonella enteritidis. Catalysis Today, 313, 79-85.

Nakawuka, P., Langan, S., Schmitter, P., \& Barron, J. (2018). A review of trends, constraints and opportunities of smallholder irrigation in East Africa. Global Food Security, 17, 196-212.

Norton-Brandão, D., Scherrenberg, S. M., \& Lier, V. J. B. (2013). Reclamation of used urban waters for irrigation purposes-A review of treatment technologies. Journal of Environmental Management, 122, 85-98.

Nousiainen, L. L., Joutsen, S., Lunden, J., Hänninen, M. L., \& Fredriksson-Ahomaa, M. (2016). Bacterial quality and safety of packaged fresh leafy vegetables at the retail level in Finland. International Journal of Food Microbiology, 232, 73-79.

Olayide, O. E., \& Alabi, T. (2018). Between Rainfall and food poverty: Assessing Vulnerability to climate change in an agricultural economy. Journal of Cleaner Production, 198, 1-10.

de Oliveira, M. A., de Souza, V. M., Bergamini, A. M. M., \& De Martinis, E. C. P. (2011). Microbiological quality of ready-to-eat minimally processed vegetables consumed in Brazil. Food Control, 22, 1400-1403.

Ömez, H., \& Kretzschmar, U. (2009). Potential alternative disinfection methods for organic fresh-cut industry forminimizing water consumption and environmental impact. Lebensmittel-Wissenschaft und -Technologie-Food Science and Technology, 42, 686-693.

Oyedeji, S., Animasaun, D. A., Bello, A. A., \& Agboola, O. O. (2014). Effect of NPK and poultry manure on growth, yield, and proximate composition of three amaranths. Journal of Botany Article ID, 828750, 6. https://doi.org/10.1155/2014/828750.

Pang, J., Feng, X., \& Wang, X. (2014). Purification and utilization of garlic processing wastewater in lotus pond wetlands. Water Science and Engineering, 7(4), 395-402.

Picó, Y., Alfarham, A., \& Barcel, D. (2017). Analysis of emerging contaminants and nanomaterials in plant materials following uptake from soils. Trends in Analytical Chemistry, 94, 173-189.

Prakash, A., Baskaran, R., Paramasivam, N., \& Vadivel, V. (2018). Essential oil based nanoemulsions to improve the microbial quality of minimally processed fruits and vegetables: A review. Food Research International, 111, 509-523.

Prosekov, A. Y., \& Ivanova, S. A. (2018). Food security: The challenge of the present. Geoforum, 91, 73-77.

Qadir, M., Wichelns, D., Raschid-Sally, L., McCornick, P. G., Drechsel, P., Bahri, A., et al. (2010). The challenges of wastewater irrigation in developing countries. Agricultural Water Management, 97, 561-568.

Qiu, J., Chen, G., Xu, J., Luo, E., Liu, Y., Wang, F., et al. (2016). In Vivo tracing of organochloride and organophosphorus pesticides in different organs of hydroponically grown Malabar spinach (Basella alba L.). Journal of Hazardous Materials, 316, 52-59.

Quansah, J. K., Kunadu, A. P.-H., Saalia, F. K., Díaz-Perez, J., \& Chen, J. (2018). Microbial quality of leafy green vegetables grown or sold in Accra metropolis, Ghana. Food Control, 86, 302-309.

Qureshi, A. S., Hussain, M. I., Ismail, S., \& Khan, Q. M. (2016). Evaluating heavy metal accumulation and potential health risks in vegetables irrigated with treated wastewater. Chemosphere, 163, 54-61.

Rekhy, R., \& McConchie, R. (2014). Promoting consumption of fruit and vegetables for better health. Have campaigns delivered on the goals? Appetite, 79, 113-123.

Richardson, S. D., \& Kimura, S. Y. (2017). Emerging environmental contaminants: Challenges facing our next generation and potential engineering solutions. Environment, Technology and Innovation, 8, 40-56.

Roy, P. K., \& Ghosh, M. (2017). Chlorine resistant bacteria isolated from drinking water treatment plants in West Bengal. Desalination and Water Treatment, 79, 103-107.

Salomonsson, H., Jacxsens, L., Perseyn, J., \& De Meulenaer, B. (2014). Risk profiling of wash waters in vegetable processing industry towards possible allergen carry-over. Food Research International, 55, 190-196.

Sanchez, G., Elizaquível, P., Aznar, R., \& Selma, M. V. (2015). Virucidal effect of high power ultrasound combined with a chemical sanitizer containing peroxyacetic acid for water reconditioning in the fresh-cut industry. Food Control, 52, 126-131.

Selma, M. V., Allende, A., Lo'pez-Ga'lvez, F., Conesa, M. A., \& Gil, M. I. (2008). Disinfection potential of ozone, ultraviolet-C and their combination in wash water for the fresh-cut vegetable industry. Food Microbiology, 25, 809-814.

Sophia, C. A., \& Lima, E. C. (2018). Removal of emerging contaminants from the environment by adsorption. Ecotoxicology and Environmental Safety, 150, 1-17.

Ssemanda, J. N., Reij, M., Bagabe, M. C., Muvunyi, C. M., Joosten, H., \& Zwietering, M. H. (2017). Indicator microorganisms in fresh vegetables from "farm to fork" in Rwanda. Food Control, 75, 126-133.

Tal, A. (2016). Rethinking the sustainability of Israel's irrigation practices in the Dry lands. Water Research, 90, 387-394.

Tamura, I., Yasuda, Y., Kagota, K., Yoneda, S., Nakada, N., Kumar, V., et al. (2017). Contribution of pharmaceuticals and personal care products (PPCPs) to whole toxicity of water samples collected in effluent-dominated urban streams. Ecotoxicology and Environmental Safety, 144, 338-350.

Teh, C. Y., Wu, T. Y., \& Juan, J. C. (2014). Optimization of agro-industrial wastewater treatment using unmodified rice starch as a natural coagulant. Industrial Crops and Products, 56, 17-26.

Terio, V., Bottaro, M., Pavoni, E., Losio, M. N., Serraino, A., Giacometti, F., et al. (2017) Occurrence of hepatitis A and E and norovirus GI and GII in ready-to-eat vegetables in Italy. International Journal of Food Microbiology, 249, 61-65.

Termeer, C. J. M. A., Drimie, S., Ingram, J., Pereira, L., \& Whittingham, M. J. (2018). A diagnostic framework for food system governance arrangements: The case of South Africa. NJAS - Wageningen Journal of Life Sciences, 84, 85-93.

Tervahauta, T., Rani, S., Leal, L. H., Buisman, C. J. M., \& Zeeman, G. (2014). Black Water sludge reuse in agriculture: Are Heavy metals a problem? Journal of Hazardous Materials, 274, 229-236.

Urbano, V. R., Mendonc, T. G., Bastos, R. G., \& Souza, C. F. (2017). Effects of treated wastewater irrigation on soil properties and lettuce yield. Agricultural Water Management, 181, 108-115.

Uusiku, N. P., Oelofse, A., Duodu, K. G., Bester, M. J., \& Faber, M. (2010). Nutritiona value of leafy vegetables of sub-saharan Africa and their potential contribution to human health: A review. Journal of Food Composition and Analysis, 23, 499-509.

Vanham, D., Hoekstra, A. Y., Wada, Y., Bouraoui, F., de Roo, A., Mekonnen, M. M., et al. (2018). Physical water scarcity metrics for monitoring progress towards SDG target 6.4: An evaluation of indicator 6.4.2 "Level of water stress". The Science of the Total Environment, 613-614, 218-232.

Vergine, P., Salerno, C., Libutti, A., Beneduce, L., Gatta, G., Berardi, G., et al. (2017). Closing the water cycle in the agro-industrial sector by reusing treated wastewater for irrigation. Journal of Cleaner Production, 164, 587-596.

Wang, Y., Ho, S., Cheng, C., Guo, W., Nagarajan, D., Ren, N., et al. (2016). Perspectives on the feasibility of using microalgae for industrial wastewater treatment. Bioresource Technology, 222, 485-497.

Wang, Y., Huang, H., \& Wei, X. (2018). Influence of wastewater precoagulation on adsorptive filtration of pharmaceutical and personal care products by carbon nanotube membranes. Chemical Engineering Journal, 333, 66-75.

Wang, X., Ouyang, Y., Liu, J., Zhu, M., Zhao, G., Bao, W., et al. (2014). Fruit and vegetable consumption and mortality from all causes, cardiovascular disease, and cancer: Systematic review and dose-response meta-analysis of prospective cohort studies. BMJ, 349(4490), 1-14.

Wang, F., Qiao, M., Chen, Z., Su, J., \& Zhu, Y. (2015). Antibiotic resistance genes in manure-amended soil and vegetables at harvest. Journal of Hazardous Materials, 299, 215-221.

Wazed, S. M., Hughes, B. R., O'Connor, D., \& Calautit, J. K. (2018). A review of sustainable solar irrigation systems for Sub-Saharan Africa. Renewable and Sustainable Energy Reviews, 81, 1206-1225.

Wilkinson, J., Hooda, P. S., Barker, J., Barton, S., \& Swinden, J. (2017). Occurrence, fate 
and transformation of emerging contaminants in water: An overarching review of the field. Environmental Pollution, 231, 954-970.

Wu, X., Ernst, F., Conkle, J. L., \& Gan, J. (2013). Comparative uptake and translocation of pharmaceutical and personal care products (PPCPs) by common vegetables. Environment International, 60, 15-22.

Xie, H., You, L., Wielgosz, B., \& Ringler, C. (2014). Estimating the potential for expanding smallholder irrigation in Sub-Saharan Africa. Agricultural Water Management, 131, 183-193.

Yang, Z., Pei, H., Hou, Q., Jiang, L., Zhang, L., \& Nie, C. (2018a). Algal biofilm-assisted microbial fuel cell to enhance domestic wastewater treatment: Nutrient, organics removal and bioenergy production. Chemical Engineering Journal, 332, 277-285.

Yang, Y., Zhao, J., Liu, Y., Liu, W., Zhang, Q., Yao, L., et al. (2018b). Pharmaceuticals and personal care products (PPCPs) and artificial sweeteners (ASs) in surface and ground waters and their application as indication of wastewater contamination. The Science of the Total Environment, 616-617, 816-823.

Yao, L., Zhao, J., Liu, Y., Zhang, Q., Jiang, Y., Liu, S., et al. (2018). Personal care products in wild fish in two main Chinese rivers: Bioaccumulation potential and human health risks. The Science of the Total Environment, 621, 1093-1102.

Yue, J., Jiang, X., Yuan, X., Wang, X., Bo Li, X., \& Liu, S. (2017). Design of a multiplexed system for domestic wastewater of Happy Farmer's Home (HFH) and environmental evaluation using the emergy analysis. Journal of Cleaner Production, 156, 729-740.

Zhang, L., Vrieze, J. D., Hendrickx, T. L. G., Wei, W., Temmink, H., Rijnaarts, H., et al. (2018). Anaerobic treatment of raw domestic wastewater in a UASB-digester at $10^{\circ} \mathrm{C}$ and microbial community dynamics. Chemical Engineering Journal, 334, 2088-2097.

Zhao, L., Deng, J., Sun, P., YiJi, J. L., Nakada, N., Qiao, Z., et al. (2018). Nanomaterials for treating emerging contaminants in water by adsorption and photocatalysis: Systematic review and bibliometric analysis. The Science of the Total Environment, 627, 1253-1263.

Zhou, J., Helen, J. H., \& Liang, J. (2011). Implementation of food safety and quality standards: A case study of vegetable processing industry in zhejiang, China. The Social Science Journal, 48, 543-552. 